\title{
The Prognostic Role of Red Blood Cell Distribution Width in Coronary Artery Disease: A Review of the Pathophysiology
}

\author{
Kamil Bujak, Jarosław Wasilewski, Tadeusz Osadnik, Sandra Jonczyk, \\ Aleksandra Kołodziejska, Marek Gierlotka, and Mariusz Gąsior \\ 3rd Department of Cardiology, SMDZ in Zabrze, Medical University of Silesia, Marii Skłodowskiej Curie Street 9, \\ 41-800 Zabrze, Poland \\ Correspondence should be addressed to Jarosław Wasilewski; jaroslaw-wasilewski@wp.pl
}

Received 18 June 2015; Revised 14 August 2015; Accepted 18 August 2015

Academic Editor: Shih-Ping Hsu

Copyright (C) 2015 Kamil Bujak et al. This is an open access article distributed under the Creative Commons Attribution License, which permits unrestricted use, distribution, and reproduction in any medium, provided the original work is properly cited.

Red blood cell distribution width (RDW) is a measure of red blood cell volume variations (anisocytosis) and is reported as part of a standard complete blood count. In recent years, numerous studies have noted the importance of RDW as a predictor of poor clinical outcomes in the settings of various diseases, including coronary artery disease (CAD). In this paper, we discuss the prognostic value of RDW in CAD and describe the pathophysiological connection between RDW and acute coronary syndrome. In our opinion, the negative prognostic effects of elevated RDW levels may be attributed to the adverse effects of independent risk factors such as inflammation, oxidative stress, and vitamin $\mathrm{D}_{3}$ and iron deficiency on bone marrow function (erythropoiesis). Elevated RDW values may reflect the intensity of these phenomena and their unfavorable impacts on bone marrow erythropoiesis. Furthermore, decreased red blood cell deformability among patients with higher RDW values impairs blood flow through the microcirculation, resulting in the diminution of oxygen supply at the tissue level, particularly among patients suffering from myocardial infarction treated with urgent revascularization.

\section{Introduction}

Red blood cell distribution width (RDW) is a parameter routinely measured by most modern hematology analyzers. RDW is defined as the quotient of standard deviation of red blood cell volume and its mean volume and is expressed as a percentage according to the following formula: RDW $=$ (standard deviation of red blood cell volume/mean cell volume) $\times 100$. Higher RDW values reflect greater variations in red blood cell volume [1].

One of the first studies to assess the role of RDW in cardiovascular disease was published by Felker et al. in 2007. The authors noted the usefulness of RDW as a prognostic marker among patients with heart failure (HF) [2]. Subsequent studies have confirmed the significance of RDW as a predictor of mortality both in the general population [3] and in patients with various diseases, including peripheral artery disease (PAD) [4], chronic obstructive pulmonary disease (COPD) [5], and kidney failure [6-8]. In the literature, there exist increasing amounts of data describing the link between RDW and prognosis in patients with stable coronary artery disease (SCAD) [9], including patients undergoing percutaneous coronary intervention (PCI) $[10]$ and patients suffering from myocardial infarction (MI) [11, 12].

The aim of this review is to describe the prognostic utility of RDW in patients with coronary artery disease (CAD) and to elucidate the mechanism underlying the relationship between elevated RDW values and poor patient prognosis in this particular group of patients.

\section{The Prognostic and Diagnostic Value of RDW in CAD}

In recent years, numerous papers have been published regarding the value of RDW in the risk stratification of patients with CAD $[4,9,10,12]$. We have, therefore, searched PubMed and Scopus for English-language articles regarding the prognostic 
and diagnostic role of RDW in patients with CAD using the following keywords: red cell distribution width; RDW; coronary artery disease; myocardial infarction; acute coronary syndrome. Additionally, we have searched reference lists of publications in this field. The most important and appropriate studies investigating the prognostic and diagnostic value of RDW in patients with CAD are summarized in Table 1.

One of the studies that assessed the prognostic role of RDW was conducted at our center. We demonstrated that RDW was an independent risk factor for long-term mortality in patients undergoing PCI for SCAD [10], and CAD patients with elevated RDW values more frequently suffered from concomitant diseases such as PAD and COPD [10]. Furthermore, RDW itself correlates with both the severity and the complexity of coronary artery atherosclerosis, as determined using the SYNTAX [43] and Gensini scores [40].

Tonelli et al. determined that RDW was a risk factor for MI, stroke, and symptomatic HF in patients with CAD [9]. Elevated RDW levels are also associated with increased inhospital and long-term mortality among patients suffering from MI [11, 12]. Lippi et al. observed that RDW had diagnostic value in patients admitted to the intensive care unit for chest pain suggestive of acute coronary syndrome. Combined measurements of both troponin T and RDW have allowed for diagnosing MI with greater sensitivity than the analysis of troponin $\mathrm{T}$ alone [36]. In patients with nonST elevation myocardial infarction, RDW may be used to predict the occurrence of fragmented QRS complexes noted on electrocardiography [46] and the absence of collateral circulation on coronary angiography [47]. Additionally, there exist publications that describe the relationship between RDW and the lack of tissue reperfusion in patients with MI treated via PCI $[44,57]$.

The results of large, prospective studies with long-term follow-up periods (Tromsø and National Health and Nutrition Examination Survey) show that elevated RDW values increase the risk of $\mathrm{MI}$ and mortality due to CAD in the general population, regardless of other known CAD risk factors $[67,69]$, including the risks of $\mathrm{MI}$ and mortality among elderly patients without aging-associated diseases [3].

One of the most important limitations affecting the longterm outcomes of CAD invasive treatment is restenosis [70] which occurs more frequently in patients with elevated RDW values, which is the case following both bare-metal [61] and antimitotic drug-eluting stent implantation [64]. RDW is also valuable in assessing the risk of major bleeding complications in patients undergoing PCI [60], as well as the risk of contrast-induced nephropathy [65]. In patients undergoing coronary artery by-pass grafting, RDW is a risk factor for atrial fibrillation following cardiac surgery [59].

One limitation to the clinical usefulness of RDW in predicting adverse clinical outcomes is its moderate sensitivity and specificity [12]. However, these parameters are often not worse than any other laboratory parameters used in risk stratification, including C-reactive protein (CRP) [67, 71]. Additionally, there are no unambiguous RDW cut-off values. In papers concerning this problem, the cut-off values vary depending on the population and adverse events studied [72]. The potential use of RDW as a predictive factor for cardiovascular events appears to reside in its utilization as an element of various risk scores.

The main limitation of the vast majority of cited studies is that they were observational and described only the statistical relationship between elevated RDW value and outcomes of patients with CAD, but not the pathophysiological mechanism explaining that phenomenon. Moreover, only a few published studies included factors influencing the hematopoiesis, that is, levels of folic acid, vitamin B12, markers of inflammation, and iron status as potential confounding factors $[72,73]$.

In summary, RDW is a significant predictor of both allcause mortality and adverse cardiovascular events in patients with CAD. Increased values of this parameter are associated with greater numbers of comorbidities and a higher likelihood of complications among patients with CAD treated via PCI.

In the following sections, the potential mechanisms explaining why elevated RDW levels are a strong, negative predictive factor among patients with $\mathrm{CAD}$ will be discussed.

\section{The Reasons for the Poor Prognosis Observed in Patients with CAD with High RDW Levels}

The influence of RDW on prognosis among patients with cardiovascular disease has been extensively studied [9-12]. Nonetheless, the reasons for the poor prognosis in this patient group remain unclear. For instance, it has not been determined whether RDW is only a marker of the severities of various disorders or if there is a direct pathophysiological relationship among anisocytosis, $\mathrm{CAD}$, and poor prognosis in patients with CAD. Most likely, numerous factors impairing bone marrow hematopoietic function, which are identical to the factors that worsen the prognoses of patients with CAD, play integral roles in this process.

3.1. Anemia, Iron, and RDW. Anemia is a well-documented mortality risk factor among patients with CAD and is prevalent in cases of elevated RDW values [74, 75]. However, elevated RDW values increase mortality in patients with CAD regardless of their baseline hemoglobin levels [10, 16]. Furthermore, RDW has prognostic value in patients without anemia [10]. On the other hand, Salisbury et al. indicated that baseline RDW is associated with development of moderatesevere anemia during hospitalization in patients with MI and without concomitant anemia at admission [76]. It is not surprising that RDW is affected by iron metabolism [73]. Grammer et al. determined that reduced iron stores, regardless of hemoglobin concentrations, increased the likelihood of coronary artery atherosclerosis [77]. Furthermore, Ponikowska et al. determined that disturbances in iron metabolism increased mortality among patients with CAD and diabetes mellitus [78]. Perhaps iron status and low hemoglobin levels are only partially responsible for the poor prognoses observed among patients with elevated RDW levels.

3.2. Lipid Abnormalities and RDW. There are reports indicating that elevated RDW values correlate with unfavorable lipid 


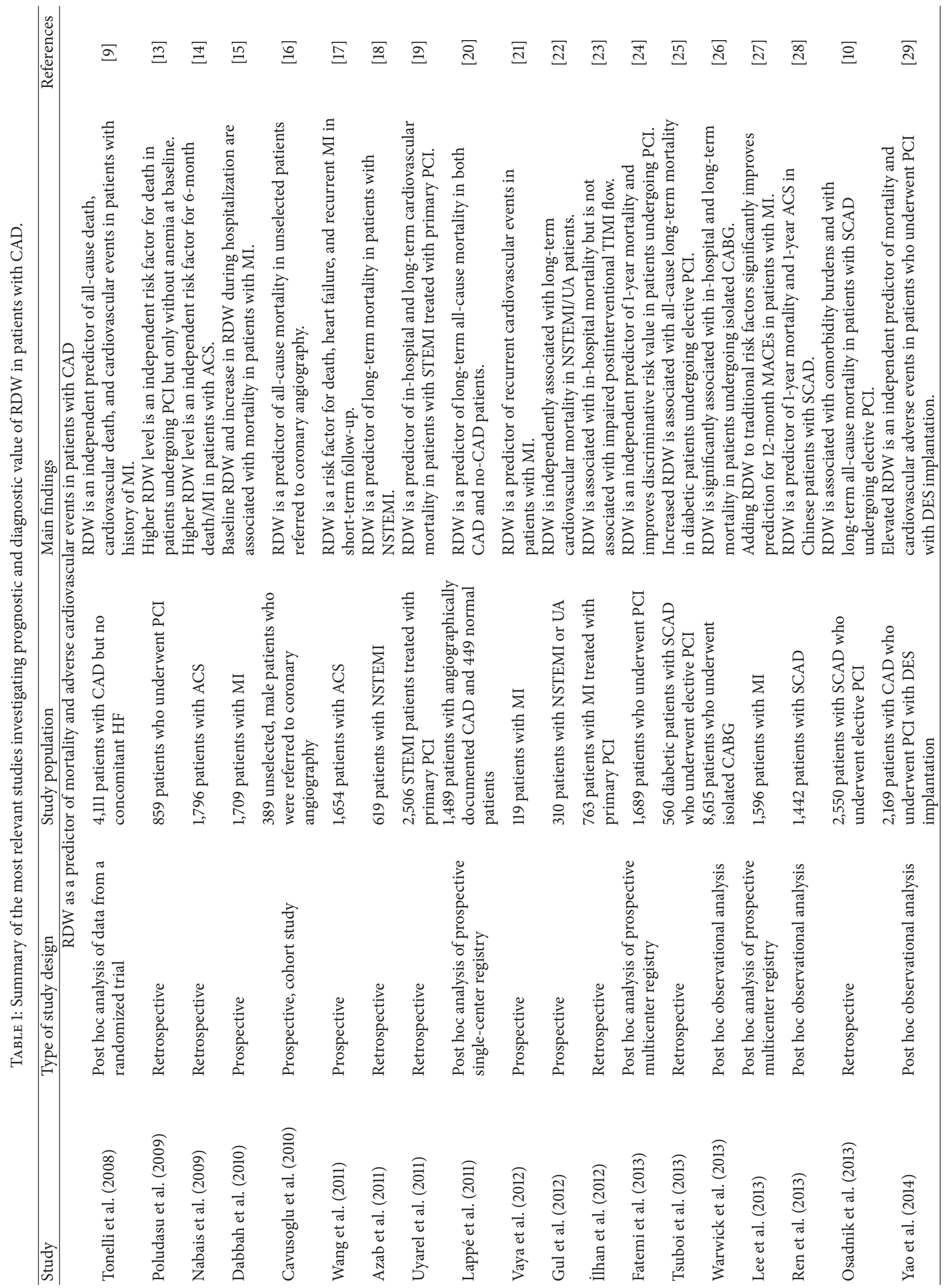




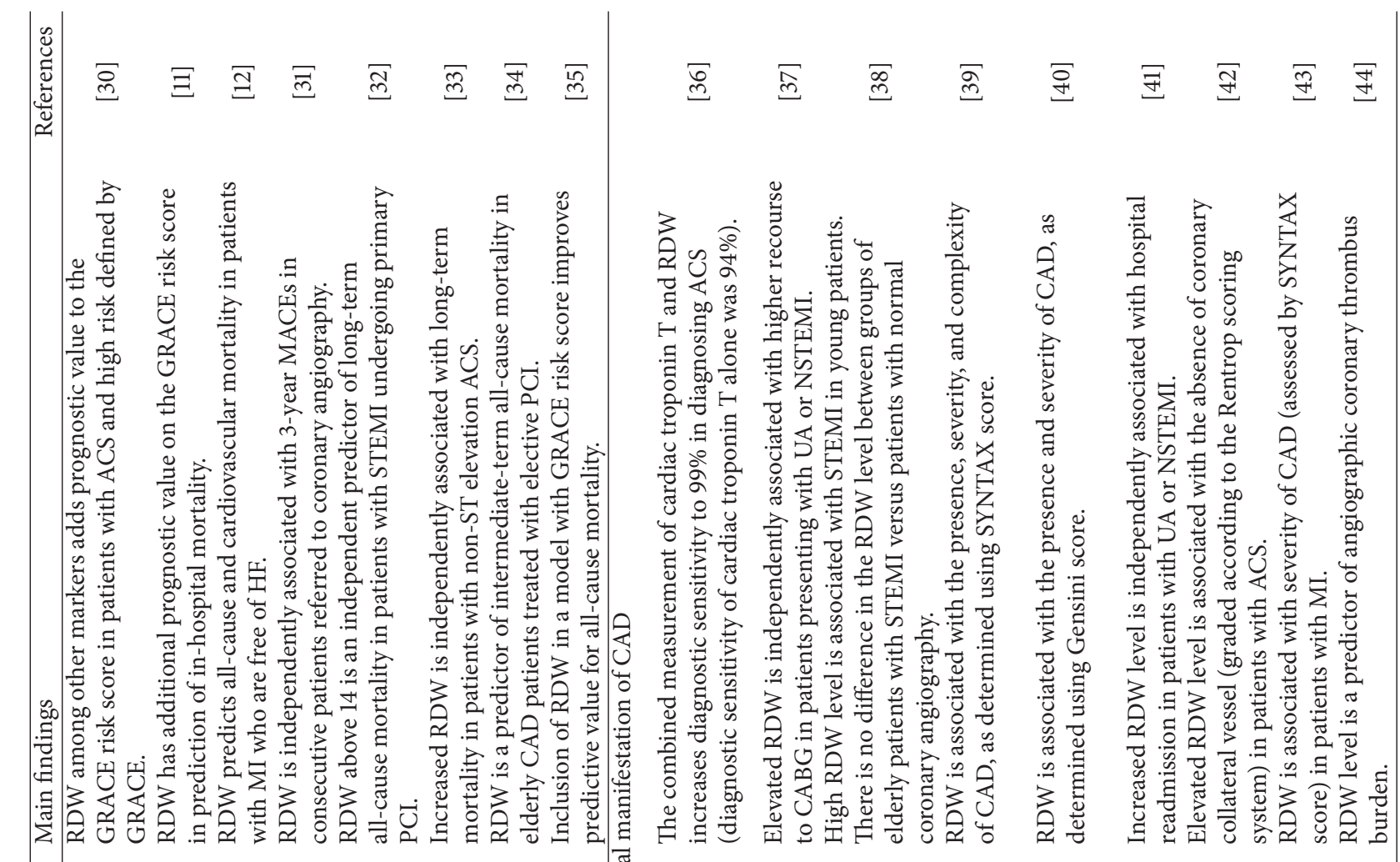

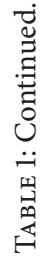
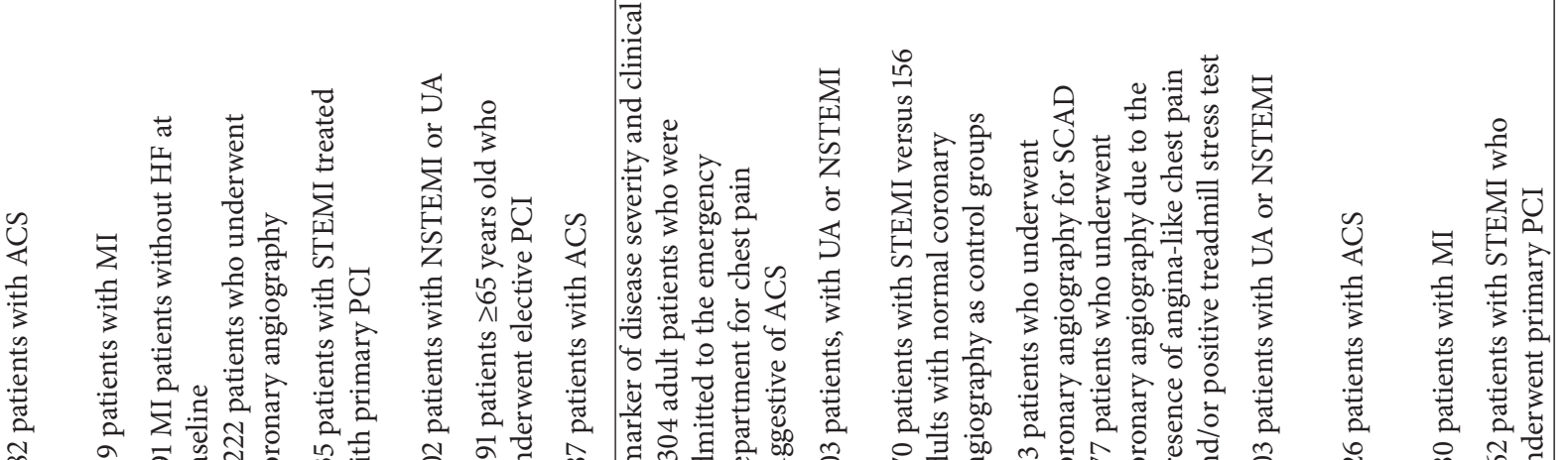

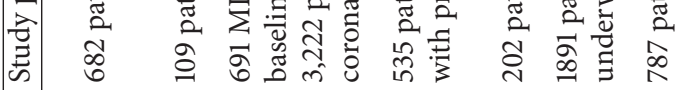

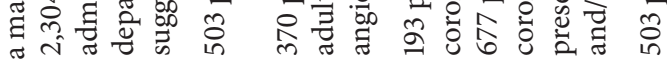

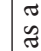

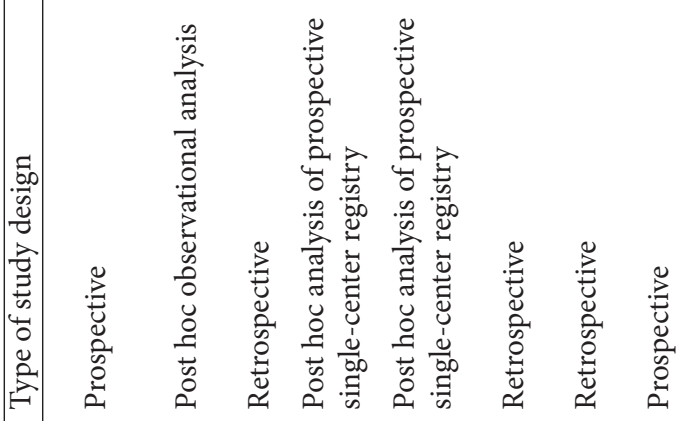

文



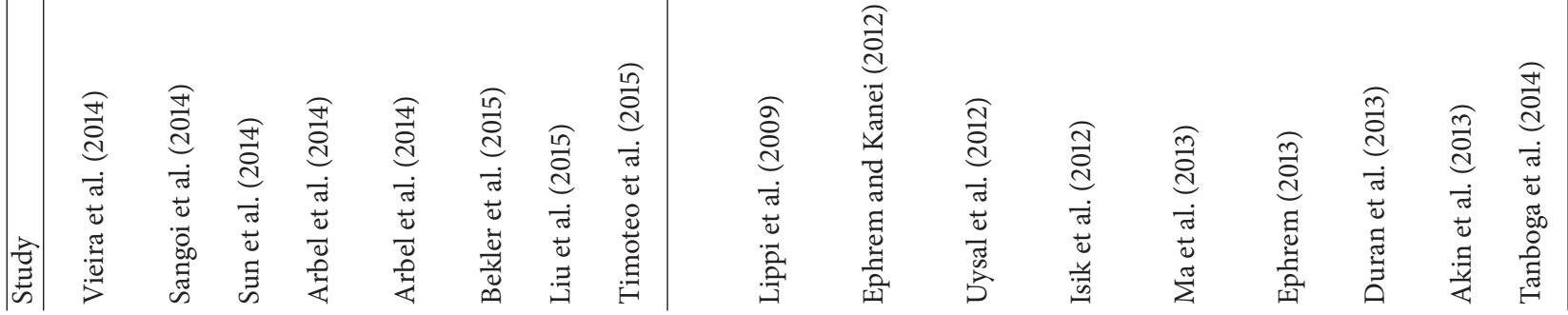




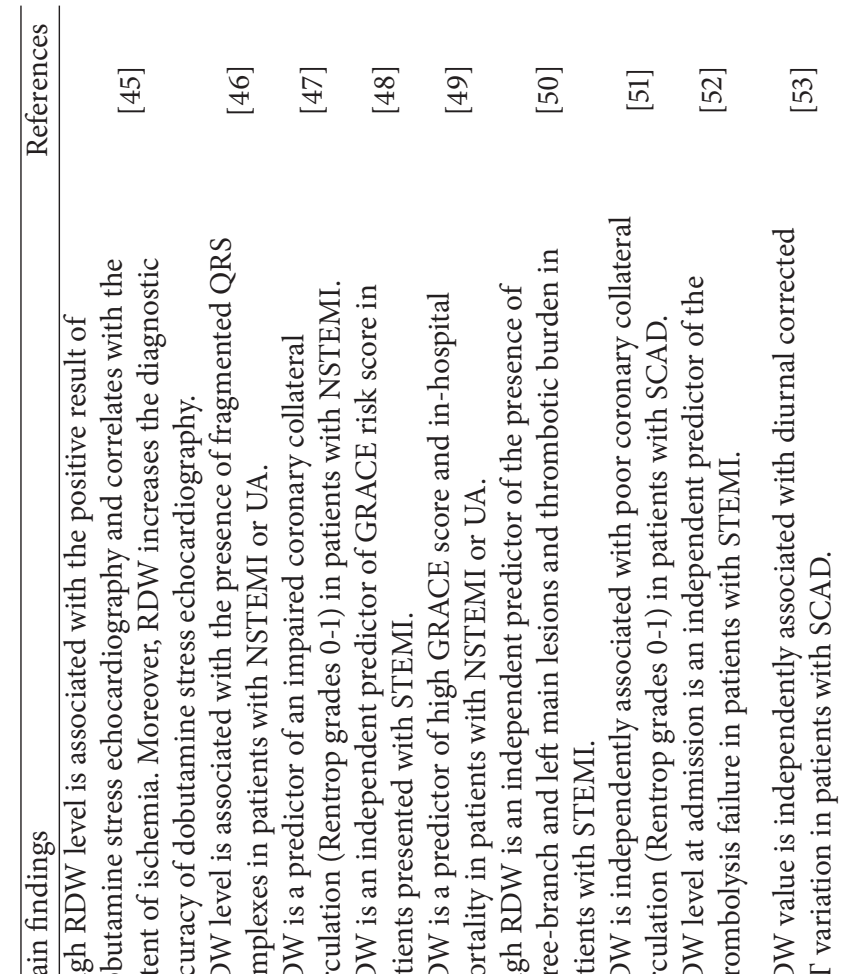

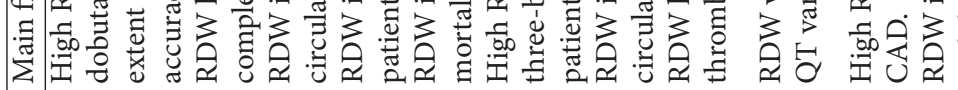

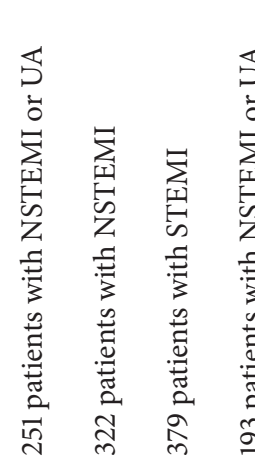

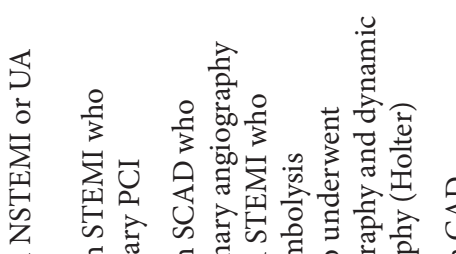

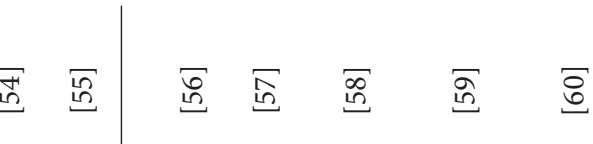



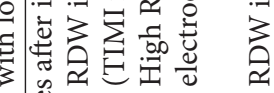

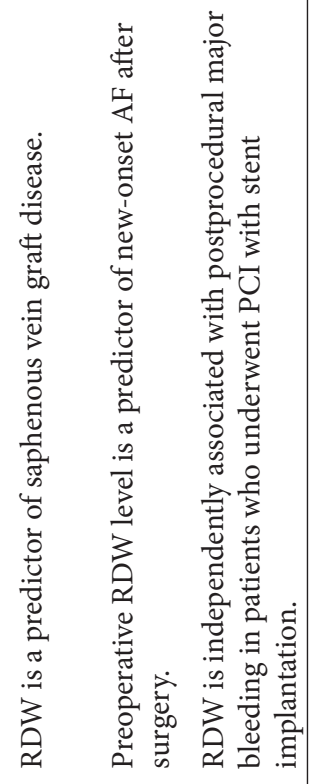

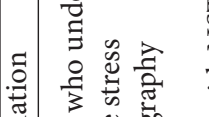

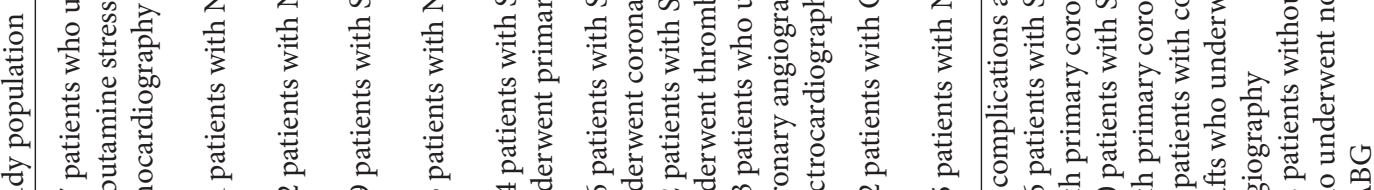



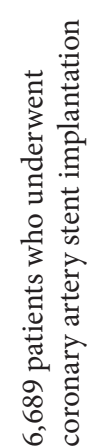

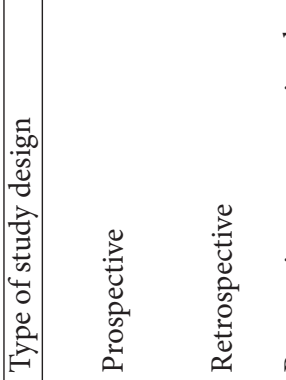

তี్ّّ



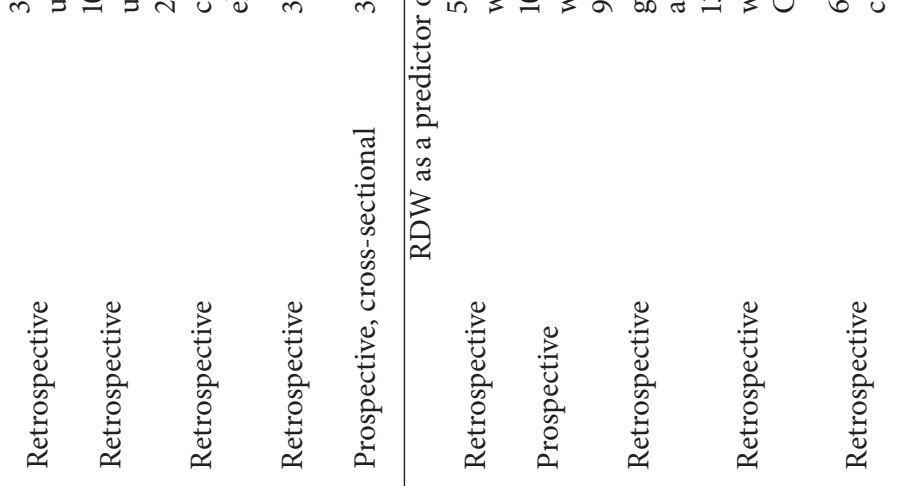

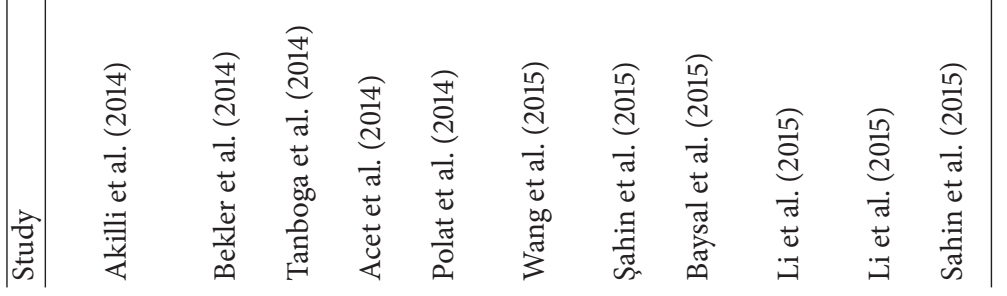

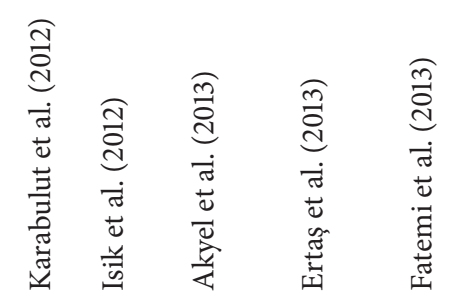




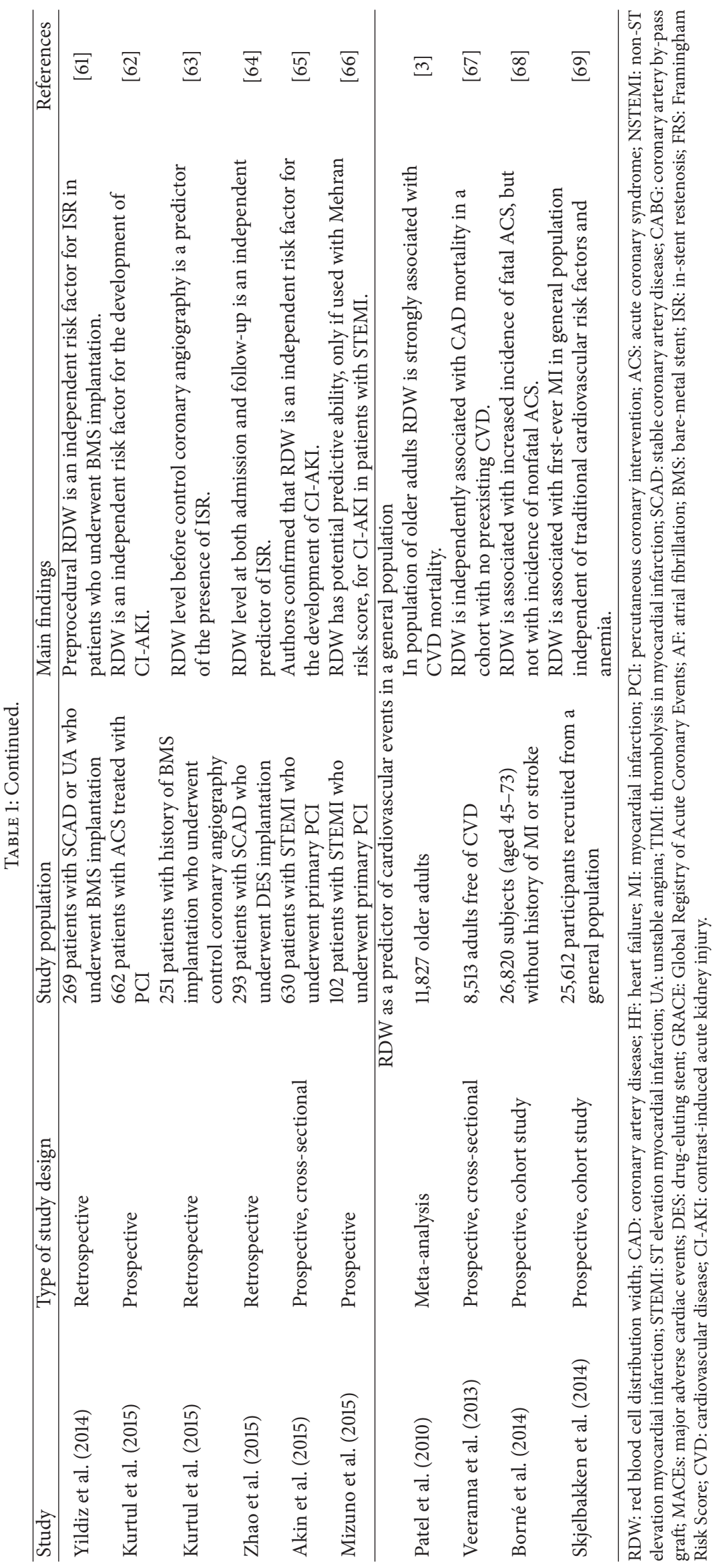


profiles $[79,80]$. Some insight into the relationship between RDW and lipid disorders was provided by Tziakas et al., who described a link between RDW and total cholesterol erythrocyte membrane (CEM) levels [81]. CEM level increases are responsible for the deterioration of cell deformability, which affects the lifespans of circulating erythrocytes, and this results in greater cellular turnover and elevated RDW values [82-84]. Previous studies have confirmed that once the necrotic core of the plaque accumulates erythrocytes, elevated CEM levels may result in plaque instability, which suggests that red blood cells may actively contribute to both plaque growth and plaque destabilization [85-87].

Lipid disorders decrease red cell membrane fluidity, and higher CEM levels result in the deterioration of blood flow through the microcirculation $[88,89]$. This mechanism may explain the well-documented relationship between red blood cell rheology and the lack of tissue reperfusion following PCI in patients suffering from MI $[56,90]$. This effect may also explain the slow flow phenomenon observed in the epicardial coronary arteries in symptomatic patients without coronary artery stenosis [91].

Previous studies have noted that statin therapy increases erythrocyte deformability $[89,92,93]$. However, Kucera et al. demonstrated that 12 weeks of atorvastatin therapy did not affect RDW levels despite improved lipid profiles [80]. It is possible that the statin therapy in question was not administered long enough to decrease erythrocyte membrane cholesterol concentrations (the mean erythrocyte lifespan is 115 days) [94].

3.3. Chronic Inflammation and RDW. Another explanation for the relationship between RDW and prognosis may be chronic inflammation. It is believed that even low-intensity inflammation plays a crucial role in atherogenesis and may be responsible for platelet activation [95, 96]. Lippi et al. described the relationship between RDW and inflammatory markers such as the erythrocyte sedimentation rate and high sensitivity CRP [97]. In previous studies, RDW correlated with interleukin-6, soluble tumor necrosis factors I and II receptor concentrations, and fibrinogen levels [73, 83, 98]. Additionally, chronic inflammation results in disorders of iron metabolism and decreases both the production of and bone marrow responsiveness to erythropoietin, resulting in impaired hematopoiesis and increased RDW levels [98-100]. The significance of both anemia and iron metabolism has been discussed previously.

3.4. Glycemic Disturbances and RDW. Veeranna et al. observed the correlation between $\mathrm{HbA}_{1 \mathrm{C}}$ levels (glycosylated hemoglobin) and RDW levels in patients without diabetes mellitus [101], and Lippi et al. observed the existence of a relationship between $\mathrm{HbA}_{1 \mathrm{C}}$ and $\mathrm{RDW}$ in an unselected population of elderly patients [102]. Additional studies have noted an increased prevalence of diabetes complications such as nephropathy and cardiovascular disease in patients with diabetes and elevated RDW levels [103, 104]. Garg et al. demonstrated that $\mathrm{HbA}_{1 \mathrm{C}}$ levels had an impact on CAD severity in patients without diabetes; therefore, these levels may be considered a mechanism linking RDW values to impaired glucose metabolism [105].

3.5. Vitamin $D_{3}$ Deficiency and RDW. Another factor potentially affecting RDW is vitamin $\mathrm{D}_{3}$ deficiency, a wellestablished CAD risk factor [106]. Vitamin $\mathrm{D}_{3}$ deficiency is responsible for both cell proliferation and erythropoiesis, and vitamin $\mathrm{D}_{3}$ concentrations in the bone marrow are more than two hundred times greater than in the blood. Even a minor decrease in serum vitamin $\mathrm{D}_{3}$ levels may result in the derangement of bone marrow erythropoiesis $[107,108]$.

3.6. Oxidative Stress and RDW. Oxidative stress is responsible for shortening the lifespan of red blood cells, which intensifies both the production and the release of young cellular forms into the circulation, which is reflected by increased RDW levels [109]. Oxidative stress also generates oxidized low-density lipoprotein forms, which play an important role in atherogenesis [110]. Kobayashi et al. demonstrated that using a vitamin E-bonded hemodialyzer resulted in decreased RDW values in a group of patients with endstage kidney disease undergoing hemodialysis. This effect was absent in patients dialyzed without vitamin E-bonded hemodialysis membranes [111]. The authors mentioned that the decreased RDW levels were accompanied by reduced whole-blood viscosity [111].

3.7. Renal Failure and RDW. Impaired kidney function increases mortality among patients with CAD [98, 112], and the relationship between low glomerular filtration rate, microalbuminuria, and elevated RDW levels has been demonstrated in previous studies $[6,8]$. Impaired kidney function, however, is most likely not a separate mechanism linking elevated RDW values to poor patient prognosis in CAD [7], because, among patients with chronic kidney disease, chronic inflammation, greater oxidative stress, lipid disorders, vitamin $\mathrm{D}_{3}$ deficiency and anemia, and increased RDW levels are often noted $[6,8,111,113,114]$.

3.8. Summary. The above-mentioned data indicate a correlation between RDW and other known atherosclerosispredictive factors, although it is impossible to clearly identify the mechanism by which high erythrocyte anisocytosis serves as a negative prognostic marker in patients with CAD. In our opinion, the prognostic value of RDW results primarily from the negative impacts of inflammation and oxidative stress, as well as those of iron and vitamin $\mathrm{D}_{3}$ deficiency, on bone marrow erythropoiesis. Additionally, concurrent red blood cell deformability diminution may result in impaired flow through the microcirculation. It is also impossible to unambiguously ascertain which concomitant factors, including lipid, glycemic and iron metabolism disturbances, anemia, vitamin $\mathrm{D}_{3}$ deficiency, oxidative stress, inflammation, and the diminution of erythrocyte membrane deformability, are the primary causes of the poor prognoses observed in patients with CAD. In the authors' opinion, the predictive utility of RDW results from the summation of each of the above-mentioned factors' negative impacts on bone marrow 
erythropoietic function. Therefore, the prognostic value of RDW reflects the intensification of these phenomena.

\section{Conclusions}

RDW is an important risk factor for both mortality and cardiovascular events in patients with SCAD or acute coronary syndrome. It has not yet been determined whether anisocytosis is the cause of the poorer prognosis observed among these patients or if it is simply a marker of multiple pathological states connected with said prognosis. In contrast to the markers of inflammation and oxidative stress, which are not routinely analyzed, RDW provides valuable information concerning prognosis in patients with CAD.

\section{Conflict of Interests}

The authors declare no conflict of interests regarding the publication of this paper.

\section{Acknowledgments}

This study utilized information and materials gathered during the implementation of the grants entitled "The Causes of Elevated Red Blood Cell Distribution Width Values in Patients with Stable Coronary Artery Disease Undergoing Elective Coronary Angiography," KNW-1-122/N/4/0, and "The Relationship between Coronary Artery Calcium Score and Coronary Artery Disease Severity Evaluated by MDCT Angiography and Hematological Indices," KNW-1$179 / \mathrm{N} / 5 / 0$, which were funded by the Medical University of Silesia, Poland. The authors would like to thank American Journal Experts and Michał Krawczyk for their assistance with the editing of this paper. They are grateful to Professor Lech Poloński for reviewing the paper.

\section{References}

[1] A. Karnad and T. R. Poskitt, "The automated complete blood cell count. Use of the red blood cell volume distribution width and mean platelet volume in evaluating anemia and thrombocytopenia," Archives of Internal Medicine, vol. 145, no. 7, pp. 1270-1272, 1985.

[2] G. M. Felker, L. A. Allen, S. J. Pocock et al., "Red cell distribution width as a novel prognostic marker in heart failure: data from the CHARM program and the duke databank," Journal of the American College of Cardiology, vol. 50, no. 1, pp. 40-47, 2007.

[3] K. V. Patel, R. D. Semba, L. Ferrucci et al., "Red cell distribution width and mortality in older adults: a meta-analysis," Journals of Gerontology Series A: Biological Sciences and Medical Sciences, vol. 65 , no. 3, pp. 258-265, 2010.

[4] Z. Ye, C. Smith, and I. J. Kullo, "Usefulness of red cell distribution width to predict mortality in patients with peripheral artery disease," The American Journal of Cardiology, vol. 107, no. 8, pp. 1241-1245, 2011.

[5] E. C. Seyhan, M. A. Ozgül, N. Tutar, I. Omür, A. Uysal, and S. Altin, "Red Blood Cell Distribution and Survival in Patients with Chronic Obstructive Pulmonary Disease," Journal ofChronic Obstructive Pulmonary Disease, vol. 10, no. 4, pp. 416424, 2013.
[6] G. Lippi, G. Targher, M. Montagnana, G. L. Salvagno, G. Zoppini, and G. C. Guidi, "Relationship between red blood cell distribution width and kidney function tests in a large cohort of unselected outpatients," Scandinavian Journal of Clinical and Laboratory Investigation, vol. 68, no. 8, pp. 745-748, 2008.

[7] Z.-Z. Li, L. Chen, H. Yuan, T. Zhou, and Z.-M. Kuang, "Relationship between red blood cell distribution width and early-stage renal function damage in patients with essential hypertension," Journal of Hypertension, vol. 32, pp. 2450-2456, 2014.

[8] M. Zhang, Y. Zhang, C. Li, and L. He, "Association between red blood cell distribution and renal function in patients with untreated type 2 diabetes mellitus," Renal Failure, vol. 37, no. 4, pp. 659-663, 2015.

[9] M. Tonelli, F. Sacks, M. Arnold, L. Moye, B. Davis, and M. Pfeffer, "Relation between red blood cell distribution width and cardiovascular event rate in people with coronary disease," Circulation, vol. 117, no. 2, pp. 163-168, 2008.

[10] T. Osadnik, J. Strzelczyk, M. Hawranek et al., "Red cell distribution width is associated with long-term prognosis in patients with stable coronary artery disease," BMC Cardiovascular Disorders, vol. 13, article 113, 2013.

[11] M. B. Sangoi, N. D. S. Guarda, A. P. P. Rödel et al., "Prognostic value of red blood cell distribution width in prediction of inhospital mortality in patients with acute myocardial infarction," Clinical Laboratory, vol. 60, no. 8, pp. 1351-1356, 2014.

[12] X.-P. Sun, W.-M. Chen, Z.-J. Sun et al., "Impact of red blood cell distribution width on long-term mortality in patients with stelevation myocardial infarction," Cardiology, vol. 128, no. 4, pp. 343-348, 2014.

[13] S. Poludasu, J. D. Marmur, J. Weedon, W. Khan, and E. Cavusoglu, "Red cell distribution width (RDW) as a predictor of long-term mortality in patients undergoing percutaneous coronary intervention," Thrombosis and Haemostasis, vol. 102, no. 3, pp. 581-587, 2009.

[14] S. Nabais, N. Losa, A. Gaspar et al., "Association between red blood cell distribution width and outcomes at six months in patients with acute coronary syndromes," Revista Portuguesa de Cardiologia, vol. 28, no. 9, pp. 905-924, 2009.

[15] S. Dabbah, H. Hammerman, W. Markiewicz, and D. Aronson, "Relation between red cell distribution width and clinical outcomes after acute myocardial infarction," American Journal of Cardiology, vol. 105, no. 3, pp. 312-317, 2010.

[16] E. Cavusoglu, V. Chopra, A. Gupta et al., "Relation between red blood cell distribution width (RDW) and all-cause mortality at two years in an unselected population referred for coronary angiography," International Journal of Cardiology, vol. 141, no. 2, pp. 141-146, 2010.

[17] Y.-L. Wang, Q. Hua, C.-R. Bai, and Q. Tang, "Relationship between red cell distribution width and short-term outcomes in acute coronary syndrome in a Chinese population," Internal Medicine, vol. 50, no. 24, pp. 2941-2945, 2011.

[18] B. Azab, E. Torbey, H. Hatoum et al., "Usefulness of red cell distribution width in predicting all-cause long-term mortality after non-ST-elevation myocardial infarction," Cardiology, vol. 119 , no. 2, pp. 72-80, 2011.

[19] H. Uyarel, M. Ergelen, G. Cicek et al., "Red cell distribution width as a novel prognostic marker in patients undergoing primary angioplasty for acute myocardial infarction," Coronary Artery Disease, vol. 22, no. 3, pp. 138-144, 2011.

[20] J. M. Lappé, B. D. Horne, S. H. Shah et al., "Red cell distribution width, C-reactive protein, the complete blood count, 
and mortality in patients with coronary disease and a normal comparison population," Clinica Chimica Acta, vol. 412, no. 2324, pp. 2094-2099, 2011.

[21] A. Vaya, J. L. Hernández, E. Zorio, and D. Bautista, "Association between red blood cell distribution width and the risk of future cardiovascular events," Clinical Hemorheology and Microcirculation, vol. 50, no. 3, pp. 221-225, 2012.

[22] M. Gul, H. Uyarel, M. Ergelen et al., "The relationship between red blood cell distribution width and the clinical outcomes in non-ST elevation myocardial infarction and unstable angina pectoris: a 3-year follow-up," Coronary Artery Disease, vol. 23, no. 5, pp. 330-336, 2012.

[23] E. İlhan, T. S. Güvenç, S. Altay et al., "Predictive value of red cell distribution width in intrahospital mortality and postintervention thrombolysis in myocardial infarction flow in patients with acute anterior myocardial infarction," Coronary Artery Disease, vol. 23, no. 7, pp. 450-454, 2012.

[24] O. Fatemi, J. Paranilam, A. Rainow et al., "Red cell distribution width is a predictor of mortality in patients undergoing percutaneous coronary intervention," Journal of Thrombosis and Thrombolysis, vol. 35, no. 1, pp. 57-64, 2013.

[25] S. Tsuboi, K. Miyauchi, T. Kasai et al., "Impact of red blood cell distribution width on long-term mortality in diabetic patients after percutaneous coronary intervention," Circulation Journal, vol. 77, no. 2, pp. 456-461, 2013.

[26] R. Warwick, N. Mediratta, M. Shaw et al., "Red cell distribution width and coronary artery bypass surgery," European Journal of Cardio-Thoracic Surgery, vol. 43, no. 6, pp. 1165-1169, 2013.

[27] J. H. Lee, D. H. Yang, S. Y. Jang et al., "Incremental predictive value of red cell distribution width for 12-month clinical outcome after acute myocardial infarction," Clinical Cardiology, vol. 36, no. 6, pp. 336-341, 2013.

[28] H. Ren, Q. Hua, M. Quan et al., "Relationship between the red cell distribution width and the one-year outcomes in Chinese patients with stable angina pectoris," Internal Medicine, vol. 52, no. 16, pp. 1769-1774, 2013.

[29] H.-M. Yao, T.-W. Sun, X.-J. Zhang et al., "Red blood cell distribution width and long-term outcome in patients undergoing percutaneous coronary intervention in the drug-eluting stenting era: a two-year cohort study," PLoS ONE, vol. 9, no. 4, Article ID e94887, 2014.

[30] C. Vieira, S. Nabais, V. Ramos et al., "Multimarker approach with cystatin $\mathrm{C}$, N-terminal pro-brain natriuretic peptide, C-reactive protein and red blood cell distribution width in risk stratification of patients with acute coronary syndromes," Revista Portuguesa de Cardiologia, vol. 33, no. 3, pp. 127-136, 2014.

[31] Y. Arbel, E. Y. Birati, A. Finkelstein et al., "Red blood cell distribution width and 3-year outcome in patients undergoing cardiac catheterization," Journal of Thrombosis and Thrombolysis, vol. 37, no. 4, pp. 469-474, 2014.

[32] Y. Arbel, Y. Shacham, A. Finkelstein et al., "Red blood cell distribution width (RDW) and long-term survival in patients with ST elevation myocardial infarction," Thrombosis Research, vol. 134, no. 5, pp. 976-979, 2014.

[33] A. Bekler, E. Tenekecioğlu, G. Erbağ et al., "Relationship between red cell distribution width and long-term mortality in patients with non-ST elevation acute coronary syndrome," The Anatolian Journal of Cardiology, 2015.

[34] X.-M. Liu, C.-S. Ma, X.-H. Liu et al., "Relationship between red blood cell distribution width and intermediate-term mortality in elderly patients after percutaneous coronary intervention," Journal of Geriatric Cardiology, vol. 12, no. 1, pp. 17-22, 2015.

[35] A. T. Timoteo, A. L. Papoila, A. Lousinha et al., "Predictive impact on mediumterm mortality of hematological parameters in Acute Coronary Syndromes: added value on top of GRACE risk score," European Heart Journal: Acute Cardiovascular Care, vol. 4, no. 2, pp. 172-179, 2015.

[36] G. Lippi, L. Filippozzi, M. Montagnana et al., "Clinical usefulness of measuring red blood cell distribution width on admission in patients with acute coronary syndromes," Clinical Chemistry and Laboratory Medicine, vol. 47, no. 3, pp. 353-357, 2009.

[37] G. Ephrem and Y. Kanei, "Elevated red blood cell distribution width is associated with higher recourse to coronary artery bypass graft," Cardiology, vol. 123, no. 3, pp. 135-141, 2012.

[38] O. K. Uysal, M. Duran, B. Ozkan et al., "Red cell distribution width is associated with acute myocardial infarction in young patients," Cardiology Journal, vol. 19, no. 6, pp. 597-602, 2012.

[39] T. Isik, H. Uyarel, I. H. Tanboga et al., "Relation of red cell distribution width with the presence, severity, and complexity of coronary artery disease," Coronary Artery Disease, vol. 23, no. 1, pp. 51-56, 2012.

[40] F.-L. Ma, S. Li, X.-L. Li et al., "Correlation of red cell distribution width with the severity of coronary artery disease: a large Chinese cohort study from a single center," Chinese Medical Journal, vol. 126, no. 6, pp. 1053-1057, 2013.

[41] G. Ephrem, "Red blood cell distribution width is a predictor of readmission in cardiac patients," Clinical Cardiology, vol. 36, no. 5, pp. 293-299, 2013.

[42] M. Duran, O. K. Uysal, O. Günebakmaz et al., "Increased red cell distribution width level is associated with absence of coronary collateral vessels in patients with acute coronary syndromes," Türk Kardiyoloji Derneği Arşivi: Türk Kardiyoloji Derneğinin yayın Organıdır, vol. 41, no. 5, pp. 399-405, 2013.

[43] F. Akin, N. Köse, B. Ayça et al., "Relation between red cell distribution width and severity of coronary artery disease in patients with acute myocardial infarction," Angiology, vol. 64, no. 8, pp. 592-596, 2013.

[44] I. H. Tanboga, S. Topcu, E. Aksakal, K. Kalkan, S. Sevimli, and M. Acikel, "Determinants of angiographic thrombus burden in patients with ST-segment elevation myocardial infarction," Clinical and Applied Thrombosis/Hemostasis, vol. 20, pp. 716722, 2014.

[45] H. Akilli, M. Kayrak, A. Aribas et al., "The relationship between red blood cell distribution width and myocardial ischemia in dobutamine stress echocardiography," Coronary Artery Disease, vol. 25, no. 2, pp. 152-158, 2014.

[46] A. Bekler, E. Gazi, E. Tenekecioglu et al., "Assessment of the relationship between red cell distribution width and fragmented QRS in patients with non-ST elevated acute coronary syndrome," Medical Science Monitor, vol. 20, pp. 413-419, 2014.

[47] I. H. Tanboga, S. Topcu, T. Nacar et al., "Relation of coronary collateral circulation with red cell distribution width in patients with non-ST elevation myocardial infarction," Clinical and Applied Thrombosis/Hemostasis, vol. 20, no. 4, pp. 411-415, 2014.

[48] H. Acet, F. Erta, M. A. Ak 1 et al., "Relationship between hematologic indices and global registry of acute coronary events risk score in patients with ST-segment elevation myocardial infarction," Clinical and Applied Thrombosis/Hemostasis, 2014.

[49] N. Polat, A. Yildiz, M. Oylumlu et al., "Relationship between red cell distribution width and the GRACE risk score with 
in-hospital death in patients with acute coronary syndrome," Clinical and Applied Thrombosis/Hemostasis, vol. 20, no. 6, pp. 577-582, 2014.

[50] P. Wang, Y. Wang, H. Li, Y. Wu, and H. Chen, "Relationship between the red blood cell distribution width and risk of acute myocardial infarction," Journal of Atherosclerosis and Thrombosis, vol. 22, no. 1, pp. 21-26, 2015.

[51] İ. Şahin, A. Karabulut, A. Kaya et al., "Increased level of red cell distribution width is associated with poor coronary collateral circulation in patients with stable coronary artery disease," Türk Kardiyoloji Derneği Arşivi: Türk Kardiyoloji Derneğinin yayın Organıdır, vol. 43, no. 2, pp. 123-130, 2015.

[52] E. Baysal, M. Çetin, B. Yaylak et al., "Roles of the red cell distribution width and neutrophil/lymphocyte ratio in predicting thrombolysis failure in patients with an ST-segment elevation myocardial infarction," Blood Coagulation and Fibrinolysis, vol. 26, pp. 274-278, 2015.

[53] Y. Li, Q. Xiao, W. Zeng et al., "Red blood cell distribution width is independently correlated with diurnal QTc variation in patients with coronary heart disease," Medicine, vol. 94, no. 23, p. e822, 2015.

[54] W. Li, X. Li, M. Wang et al., "Association between red cell distribution width and the risk of heart events in patients with coronary artery disease," Experimental and Therapeutic Medicine, vol. 9, no. 4, pp. 1508-1514, 2015.

[55] O. Sahin, M. Akpek, B. Sarli et al., "Association of red blood cell distribution width levels with severity of coronary artery disease in patients with non-st elevation myocardial infarction," Medical Principles and Practice, vol. 24, no. 2, 2015.

[56] A. Karabulut, H. Uyarel, B. Uzunlar, and M. Çakmak, "Elevated red cell distribution width level predicts worse postinterventional thrombolysis in myocardial infarction flow reflecting abnormal reperfusion in acute myocardial infarction treated with a primary coronary intervention," Coronary Artery Disease, vol. 23, no. 1, pp. 68-72, 2012.

[57] T. Isik, M. Kurt, E. Ayhan, I. H. Tanboga, M. Ergelen, and H. Uyarel, "The impact of admission red cell distribution width on the development of poor myocardial perfusion after primary percutaneous intervention," Atherosclerosis, vol. 224, no. 1, pp. 143-149, 2012.

[58] A. Akyel, I. E. Çelik, F. Öksüz et al., "Red blood cell distribution width in saphenous vein graft disease," Canadian Journal of Cardiology, vol. 29, no. 4, pp. 448-451, 2013.

[59] G. Ertaş, C. Aydin, O. Sönmez et al., "Red cell distribution width predicts new-onset atrial fibrillation after coronary artery bypass grafting," Scandinavian Cardiovascular Journal, vol. 47, no. 3, pp. 132-135, 2013.

[60] O. Fatemi, R. Torguson, F. Chen et al., "Red cell distribution width as a bleeding predictor after percutaneous coronary intervention," The American Heart Journal, vol. 166, no. 1, pp. 104-109, 2013.

[61] A. Yildiz, F. Tekiner, A. Karakurt, G. Sirin, and D. Duman, "Preprocedural red blood cell distribution width predicts bare metal stent restenosis," Coronary Artery Disease, vol. 25, no. 6, pp. 469-473, 2014.

[62] A. Kurtul, M. Yarlioglues, S. N. Murat et al., "Red cell distribution width predicts contrast-induced nephropathy in patients undergoing percutaneous coronary intervention for acute coronary syndrome," Angiology, vol. 66, pp. 433-440, 2015.

[63] A. Kurtul, S. N. Murat, M. Yarlioglues et al., "The association of red cell distribution width with in-stent restenosis in patients with stable coronary artery disease," Platelets, vol. 26, no. 1, pp. 48-52, 2015.

[64] K. Zhao, Y.-J. Li, and S. Gao, "Role of red blood cell distribution in predicting drug-eluting stent restenosis in patients with stable angina pectoris after coronary stenting," Coronary Artery Disease, vol. 26, pp. 220-224, 2015.

[65] F. Akin, O. Celik, I. Altun et al., "Relation of red cell distribution width to contrast-induced acute kidney injury in patients undergoing a primary percutaneous coronary intervention," Coronary Artery Disease, vol. 26, no. 4, pp. 289-295, 2015.

[66] A. Mizuno, S. Ohde, Y. Nishizaki, Y. Komatsu, and K. Niwa, "Additional value of the red blood cell distribution width to the Mehran risk score for predicting contrast-induced acute kidney injury in patients with ST-elevation acute myocardial infarction," Journal of Cardiology, vol. 66, no. 1, pp. 41-45, 2015.

[67] V. Veeranna, S. K. Zalawadiya, S. Panaich, K. V. Patel, and L. Afonso, "Comparative analysis of red cell distribution width and high sensitivity C-reactive protein for coronary heart disease mortality prediction in multi-ethnic population: findings from the 1999-2004 NHANES," International Journal of Cardiology, vol. 168, no. 6, pp. 5156-5161, 2013.

[68] Y. Borné, J. G. Smith, O. Melander, and G. Engström, “Red cell distribution width in relation to incidence of coronary events and case fatality rates: a population-based cohort study," Heart, vol. 100, no. 14, pp. 1119-1124, 2014.

[69] T. Skjelbakken, J. Lappegard, T. S. Ellingsen et al., "Red cell distribution width is associated with incident myocardial infarction in a general population: the Tromsø study," Journal of the American Heart Association, vol. 3, no. 4, Article ID e001109, 2014.

[70] T. Osadnik, J. Strzelczyk, K. Bujak et al., "Functional polymorphism rs710218 in the gene coding GLUT1 protein is associated with in-stent restenosis," Biomarkers in Medicine, 2015.

[71] W. He, J. Jia, J. Chen et al., "Comparison of prognostic value of red cell distribution width and NT-proBNP for short-term clinical outcomes in acute heart failure patients," International Heart Journal, vol. 55, no. 1, pp. 58-64, 2014.

[72] E. Sertoglu, S. Tapan, and M. Uyanik, "Important details about the red cell distribution width," Journal of Atherosclerosis and Thrombosis, vol. 22, no. 2, pp. 219-220, 2015.

[73] Z. Förhécz, T. Gombos, G. Borgulya, Z. Pozsonyi, Z. Prohászka, and L. Jánoskuti, "Red cell distribution width in heart failure: prediction of clinical events and relationship with markers of ineffective erythropoiesis, inflammation, renal function, and nutritional state," American Heart Journal, vol. 158, no. 4, pp. 659-666, 2009.

[74] S. Muzzarelli and M. Pfisterer, "Anemia as independent predictor of major events in elderly patients with chronic angina," American Heart Journal, vol. 152, no. 5, pp. 991-996, 2006.

[75] N. Aung, H. Z. Ling, A. S. Cheng et al., "Expansion of the red cell distribution width and evolving iron deficiency as predictors of poor outcome in chronic heart failure," International Journal of Cardiology, vol. 168, no. 3, pp. 1997-2002, 2013.

[76] A. C. Salisbury, A. P. Amin, K. J. Reid et al., "Red blood cell indices and development of hospital-acquired anemia during acute myocardial infarction," American Journal of Cardiology, vol. 109, no. 8, pp. 1104-1110, 2012.

[77] T. B. Grammer, M. E. Kleber, G. Silbernagel et al., "Hemoglobin, iron metabolism and angiographic coronary artery disease (The Ludwigshafen Risk and Cardiovascular Health Study)," Atherosclerosis, vol. 236, no. 2, pp. 292-300, 2014. 
[78] B. Ponikowska, T. Suchocki, B. Paleczny et al., "Iron status and survival in diabetic patients with coronary artery disease," Diabetes Care, vol. 36, no. 12, pp. 4147-4156, 2013.

[79] G. Lippi, F. Sanchis-Gomar, E. Danese, and M. Montagnana, "Association of red blood cell distribution width with plasma lipids in a general population of unselected outpatients," Kardiologia Polska, vol. 71, no. 9, pp. 931-936, 2013.

[80] M. Kucera, D. Balaz, P. Kruzliak et al., "The effects of atorvastatin treatment on the mean platelet volume and red cell distribution width in patients with dyslipoproteinemia and comparison with plasma atherogenicity indicators-a pilot study," Clinical Biochemistry, vol. 48, no. 9, pp. 557-561, 2015.

[81] D. Tziakas, G. Chalikias, A. Grapsa, T. Gioka, I. Tentes, and S. Konstantinides, "Red blood cell distribution width-a strong prognostic marker in cardiovascular disease-is associated with cholesterol content of erythrocyte membrane," Clinical Hemorheology and Microcirculation, vol. 51, no. 4, pp. 243-254, 2012.

[82] J. Stuart and G. B. Nash, "Red cell deformability and haematological disorders," Blood Reviews, vol. 4, no. 3, pp. 141-147, 1990.

[83] A. Vayá, A. Sarnago, O. Fuster, R. Alis, and M. Romagnoli, "Influence of inflammatory and lipidic parameters on red blood cell distribution width in a healthy population," Clinical Hemorheology and Microcirculation, vol. 59, no. 4, pp. 379-385, 2015.

[84] J. Egberts, M. R. Hardeman, and L. M. Luykx, "Decreased deformability of donor red blood cells after intrauterine transfusion in the human fetus: possible reason for their reduced life span?" Transfusion, vol. 44, no. 8, pp. 1231-1237, 2004.

[85] D. N. Tziakas, J. C. Kaski, G. K. Chalikias et al., "Total cholesterol content of erythrocyte membranes is increased in patients with acute coronary syndrome: a new marker of clinical instability?" Journal of the American College of Cardiology, vol. 49, no. 21, pp. 2081-2089, 2007.

[86] M.-M. Yu, Y. Xu, J.-H. Zhang et al., "Total cholesterol content of erythrocyte membranes levels are associated with the presence of acute coronary syndrome and high sensitivity C-reactive protein," International Journal of Cardiology, vol. 145, no. 1, pp. 57-58, 2010.

[87] J. Zhang, K. Tu, Y. Xu et al., "Sphingomyelin in erythrocyte membranes increases the total cholesterol content of erythrocyte membranes in patients with acute coronary syndrome," Coronary Artery Disease, vol. 24, no. 5, pp. 361-367, 2013.

[88] M. Ercan, D. Konukoğlu, T. Erdem, and S. Onen, "The effects of cholesterol levels on hemorheological parameters in diabetic patients," Clinical Hemorheology and Microcirculation, vol. 26, no. 4, pp. 257-263, 2002.

[89] K. V. Patel, J. G. Mohanty, B. Kanapuru, C. Hesdorffer, W. B. Ershler, and J. M. Rifkind, "Association of the red cell distribution width with red blood cell deformability," Advances in Experimental Medicine and Biology, vol. 765, pp. 211-216, 2013.

[90] A. Toth, J. Papp, M. Rabai et al., "The role of hemorheological factors in cardiovascular medicine," Clinical Hemorheology and Microcirculation, vol. 56, no. 3, pp. 197-204, 2014.

[91] I. Akpinar, M. R. Sayin, Y. C. Gursoy et al., "Plateletcrit and red cell distribution width are independent predictors of the slow coronary flow phenomenon," Journal of Cardiology, vol. 63, no. 2, pp. 112-118, 2014.

[92] M. Kohno, K.-I. Murakawa, K. Yasunari et al., "Improvement of erythrocyte deformability by cholesterol-lowering therapy with pravastatin in hypercholesterolemic patients," Metabolism: Clinical and Experimental, vol. 46, no. 3, pp. 287-291, 1997.
[93] P. Miossec, F. Zkhiri, J. Pariès, M. David-Dufilho, M. A. Devynck, and P. E. Valensi, "Effect of pravastatin on erythrocyte rheological and biochemical properties in poorly controlled Type 2 diabetic patients," Diabetic Medicine, vol. 16, no. 5, pp. 424-430, 1999.

[94] R. S. Franco, "Measurement of red cell lifespan and aging," Transfusion Medicine and Hemotherapy, vol. 39, no. 5, pp. 302307, 2012.

[95] A. Owczarek, M. Babińska, B. Szyguła-Jurkiewicz, and J. Chudek, "Chronic inflammation in patients with acute coronary syndrome and chronic kidney disease," Kardiologia Polska, vol. 69, no. 4, pp. 388-393, 2011.

[96] B. Hudzik, J. Szkodzinski, J. Gorol et al., "Platelet-to-lymphocyte ratio is a marker of poor prognosis in patients with diabetes mellitus and ST-elevation myocardial infarction," Biomarkers in Medicine, vol. 9, no. 3, pp. 199-207, 2015.

[97] G. Lippi, G. Targher, M. Montagnana, G. L. Salvagno, G. Zoppini, and G. C. Guidi, "Relation between red blood cell distribution width and inflammatory biomarkers in a large cohort of unselected outpatients," Archives of Pathology and Laboratory Medicine, vol. 133, no. 4, pp. 628-632, 2009.

[98] M. E. Emans, K. Van Der Putten, K. L. Van Rooijen et al., "Determinants of Red Cell Distribution Width (RDW) in cardiorenal patients: RDW is not related to erythropoietin resistance," Journal of Cardiac Failure, vol. 17, no. 8, pp. 626-633, 2011.

[99] A. M. Konijn, "5 Iron metabolism in inflammation," Baillière's Clinical Haematology, vol. 7, no. 4, pp. 829-849, 1994.

[100] C. N. Pierce and D. F. Larson, "Inflammatory cytokine inhibition of erythropoiesis in patients implanted with a mechanical circulatory assist device," Perfusion, vol. 20, no. 2, pp. 83-90, 2005.

[101] V. Veeranna, S. K. Zalawadiya, S. S. Panaich, K. Ramesh, and L. Afonso, "The association of red cell distribution width with glycated hemoglobin among healthy adults without diabetes mellitus," Cardiology, vol. 122, no. 2, pp. 129-132, 2012.

[102] G. Lippi, G. Targher, G. L. Salvagno, and G. C. Guidi, "Increased red blood cell distribution width (RDW) is associated with higher glycosylated hemoglobin (HbAlc) in the elderly," Clinical Laboratory, vol. 60, no. 12, pp. 2095-2098, 2014.

[103] C. J. Magri and S. Fava, "Red blood cell distribution width and diabetes-associated complications," Diabetes and Metabolic Syndrome, vol. 8, no. 1, pp. 13-17, 2014.

[104] N. Malandrino, W. C. Wu, T. H. Taveira, H. B. Whitlatch, and R. J. Smith, "Association between red blood cell distribution width and macrovascular and microvascular complications in diabetes," Diabetologia, vol. 55, no. 1, pp. 226-235, 2012.

[105] N. Garg, N. Moorthy, A. Kapoor et al., "Hemoglobin A(1c) in nondiabetic patients: an independent predictor of coronary artery disease and its severity," Mayo Clinic Proceedings, vol. 89, pp. 908-916, 2014.

[106] V. Kunadian, G. A. Ford, B. Bawamia, W. Qiu, and J. E. Manson, "Vitamin D deficiency and coronary artery disease: a review of the evidence," The American Heart Journal, vol. 167, no. 3, pp. 283-291, 2014.

[107] J. J. Sim, P. T. Lac, I. L. A. Liu et al., "Vitamin D deficiency and anemia: a cross-sectional study," Annals of Hematology, vol. 89, no. 5, pp. 447-452, 2010.

[108] P. H. A. Bours, J. P. M. Wielders, J. R. Vermeijden, and A. van de Wiel, "Seasonal variation of serum 25-hydroxyvitamin D levels in adult patients with inflammatory bowel disease," Osteoporosis International, vol. 22, no. 11, pp. 2857-2867, 2011. 
[109] J. S. Friedman, M. F. Lopez, M. D. Fleming et al., "SOD2deficiency anemia: protein oxidation and altered protein expression reveal targets of damage, stress response, and antioxidant responsiveness," Blood, vol. 104, no. 8, pp. 2565-2573, 2004.

[110] P.-Y. Zhang, X. Xu, and X.-C. Li, "Cardiovascular diseases: oxidative damage and antioxidant protection," European Review for Medical and Pharmacological Sciences, vol. 18, pp. 3091-3096, 2014.

[111] S. Kobayashi, H. Moriya, K. Aso, and T. Ohtake, "Vitamin E-bonded hemodialyzer improves atherosclerosis associated with a rheological improvement of circulating red blood cells," Kidney International, vol. 63, no. 5, pp. 1881-1887, 2003.

[112] T. Osadnik, J. Wasilewski, A. Lekston et al., "Comparison of modification of diet in renal disease and chronic kidney disease epidemiology collaboration formulas in predicting long-term outcomes in patients undergoing stent implantation due to stable coronary artery disease," Clinical Research in Cardiology, vol. 103, no. 7, pp. 569-576, 2014.

[113] A. Parikh, H. S. Chase, L. Vernocchi, and L. Stern, "Vitamin D resistance in chronic kidney disease (CKD)," BMC Nephrology, vol. 15, no. 1, article 47, 2014.

[114] B. Afsar, M. Saglam, C. Yuceturk, and E. Agca, “The relationship between red cell distribution width with erythropoietin resistance in iron replete hemodialysis patients," European Journal of Internal Medicine, vol. 24, no. 3, pp. e25-e29, 2013. 




The Scientific World Journal
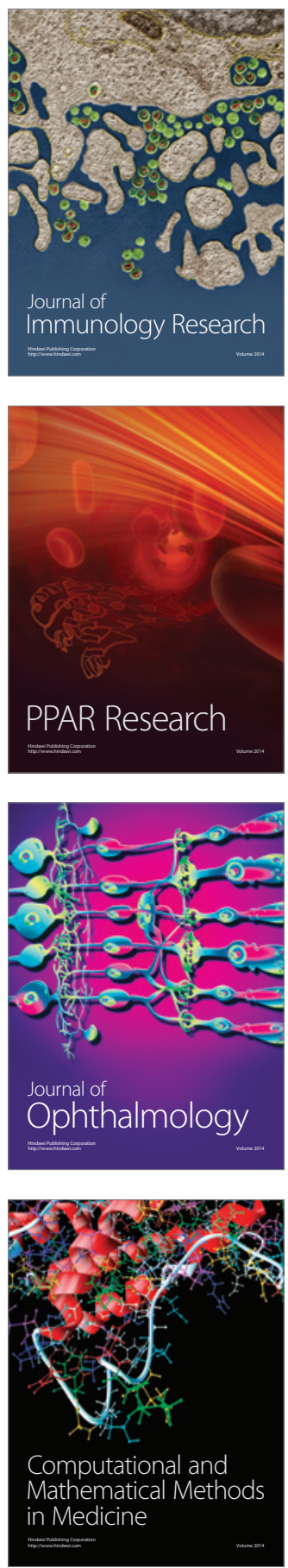



Gastroenterology

Research and Practice
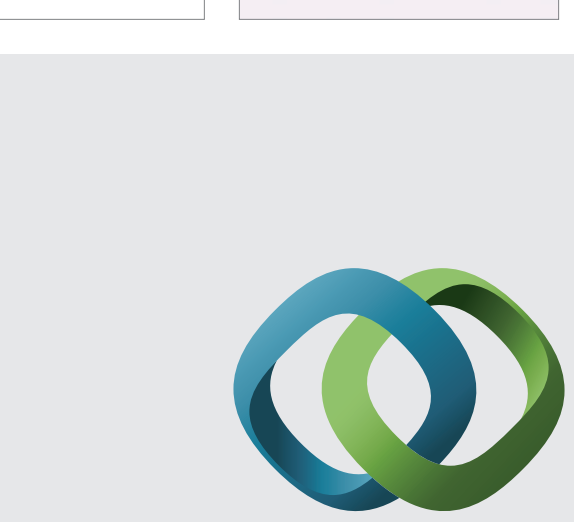

\section{Hindawi}

Submit your manuscripts at

http://www.hindawi.com

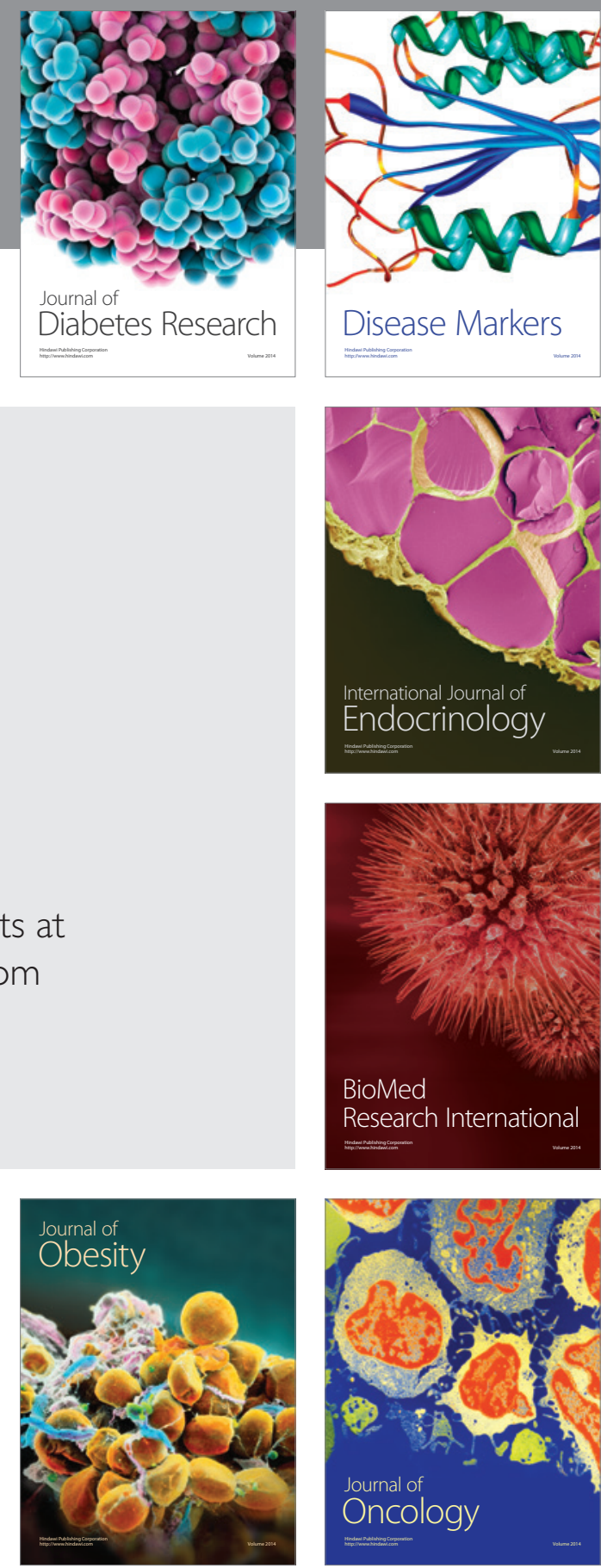

Disease Markers
